\title{
"The Role of Domestic Tourism in Supporting the National Economy, from the Point View of Employers" Field Study on Aqaba Economical City
}

\author{
Hanem Rajab Ibrahem Al-Darwesh ${ }^{1}$ \\ ${ }^{1}$ Aqaba College, Al Balqa Applied University, Aqaba, Jordan \\ Correspondence: Hanem Rajab Ibrahem Al-Darwesh, Aqaba College, Al Balqa Applied University, Aqaba, \\ Jordan.
}

Received: May 19, 2017

Accepted: June 6, $2017 \quad$ Online Published: June 7, 2017

doi:10.5539/ibr.v10n7p34

URL: https://doi.org/10.5539/ibr.v10n7p34

\begin{abstract}
The research dealt with the role of internal tourism in supporting the Jordanian economy, considering that Aqaba is a special case that represents an important part of the Jordanian domestic tourism. The problem of the research was to answer the following questions: Is Aqaba area characterized as an attractive tourist destination? Is Aqaba special economic zone authority (ASEZA) contributes to increase the Jordanian national income? Is the lack of infrastructure considers an obstacle to the development of domestic tourism in Aqaba? The data collected through the questionnaire were consisted of 30 paragraphs using the forth Likert scale.

The importance of the research lies in its benefits to the decision makers of (ASEZA) in avoiding some of the obstacles and pitfalls that face employers and tourists. Data were collected from employers in Aqaba by using simple random sampling. Analytical descriptive methods, standard deviations, percentages, and T-tests were used. The results of the research showed that there are special characteristics that promote the internal tourism in Aqaba. It concluded that (ASEZA) plays a large role in promoting the internal tourism to Aqaba through tourism awareness and through providing the infrastructure and metadata. In contrast, the research found obstacles that hinder the internal tourism to Aqaba, and the high cost of tourism was one of them. The research recommended the need to intensify the planned advertisements and promotions according to the tourist seasons, establish extra parking spaces and hotel rooms, and conduct other researches that represent the tourist's opinion themselves.
\end{abstract}

Keywords: analytical descriptive methods, Aqaba Special Economic Zone Authority (ASEZA), domestic tourism, forth Likert scale

\section{Introduction}

Jordan has a distinctive strategic location bestowed from Allah, as a gift giving it a competitive advantage in the several tourist areas from extreme north to extreme south, which may not be available in another country. Several successive civilizations revolve on Jordan, their marks stand as a witness until today, and Jordan is a gate for Islamic victories and on the Jordanian territory, great historical battles took place such as Yarmouk, Mu'tah and Pella. Jordan also has a lot of shrines and Islamic and Christian holy places, it embraces the remains of distinguished companions along its land, and it is rich in resorts and spas in different areas which characterized as a unique geographical diversity.

Aqaba takes up a distinctive position on the Jordan tourist map, as well as its economic importance for being the only marine port which connects Jordan to the world via the red sea. Besides, it considers as an important starting point for Jordan visitors coming to it across the sea to explore the historical and archaeological monuments in the south Jordan regions, such as Petra, Wadi Rum, Thana biosphere, and other locations, where areas closeness and distances shortness between Aqaba and those places allow visitors to spend more time visiting it.

But there are some important obstacles that stand in the face of the internal tourist movement to Aqaba, such as absence of development plans, poor infrastructure and metadata, and lack of coordination among various relevant parties.

It is possible to say that the hypothesis of this research suggests that Jordan in general and Aqaba in particular, 
bless with strategical tourist potentials that could achieve significant financial surpluses and plentiful social returns, remarkably human resources development, employment opportunities achievement, and tourism investment attraction with the condition of putting a strategic plan to promote Aqaba internally for the purpose of attracting more Jordanian visitors.

\section{Research Problem}

The internal tourism in the present time represent a significant economical activity that countries compose to develop for being an economical resource that contributes to the increase in the national income. Tourism activity in the Hashemite Kingdom of Jordan becomes the concern of development plans strategies in the Kingdom for the purpose of investing the tourist potentials, and directing residents to the domestic tourism. Aqaba zone possess a variety of tourist potentials, but in spite of the importance and the ability of these potentials to provide an active tourist activity, it haven't invested in a development way, and the efforts in the tourist development field haven't lived up to the optimization of tourist potentials in the Aqaba zone, not only in the area of infrastructure services that serve the tourist development, but also in the field of studies and researches that call attention to the possibilities and potentials of Aqaba zone as a tourist area. In light of this, the research tries to put emphasis on the Aqaba zone tourism potentials in the human, cultural, and natural fields, highlight those potentials, highlight Aqaba tourist role in the development of the Jordanian economy, provide employment opportunities, local community development, and the needs of Aqaba for fundamental infrastructure and overhead to serve the tourism sector. This research comes to put emphasis on the Aqaba zone tourism potentials for the goal of integration between the kingdom areas in the tourism field. Therefore, researcher can formulate the research questions as follows:

Does Aqaba zone differentiate with natural potentials at distinctive characteristics that help the tourism attraction?

What are the roles of commissariat region of (ASEZA) in developing tourism at economic Aqaba city?

What are the obstacles of internal tourism development at Aqaba zone?

\section{Research Importance}

The importance of this research return to its focus on an important tourist resource in the Hashemite kingdom of Jordan, which is Aqaba zone, where its location makes it a central region in terms of tourism, despite its far distance from the capital of Amman, and it has an important role in advancing the development acceleration. Therefore, this research came to highlight the tourism potentials that Aqaba region possess and haven't been utilized so far, which will contribute in providing a clear vision for those who have interest in the tourism development affairs, especially in the present time, where the tourism activity attain a great attention by (ASEZA), the tourism ministry, the tourism development board, and the tourism and travel offices, as well as attract the tourism investment, especially domestic or internal tourism to this region, and recover it economically and socially. Table 1, refer to the several potentials that Aqaba city acquire, such as hotels, restaurants, car rental offices, diving centers, water sports, and many others. The table shows numbers and types of those potentials which deserve total support from all parties.

Table 1. The internal tourism potentials for the economic Aqaba city during the period (2010-2016)

\begin{tabular}{ccccccccc}
\hline Years & Hotels & $\begin{array}{c}\text { Tourism } \\
\text { agencies }\end{array}$ & $\begin{array}{c}\text { Tourism } \\
\text { restaurants }\end{array}$ & $\begin{array}{c}\text { Car rental } \\
\text { offices }\end{array}$ & $\begin{array}{c}\text { Tourism } \\
\text { shops }\end{array}$ & Diving centers & $\begin{array}{c}\text { Water } \\
\text { sports }\end{array}$ & $\begin{array}{c}\text { Overall } \\
\text { employment }\end{array}$ \\
\hline 2010 & 2.583 & 200 & 1.664 & 38 & 65 & 48 & 125 & 4.723 \\
2011 & 2.583 & 200 & 1.664 & 38 & 77 & 48 & 125 & 4.735 \\
2012 & 2.719 & 177 & 1.664 & 38 & 82 & 48 & 125 & 4.853 \\
2013 & 2.735 & 153 & 1.664 & 38 & 82 & 48 & 125 & 4.845 \\
2014 & 2.753 & 156 & 1.664 & 38 & 82 & 48 & 125 & 4.866 \\
2015 & 2.753 & 156 & 1.664 & 38 & 82 & 48 & 125 & 4.866 \\
2016 & 2.753 & 156 & 1.664 & 38 & 82 & 148 & 255 & 5.096 \\
\hline
\end{tabular}

Source: Ministry of tourism and antiquities (2016).

Table 1 refer to the number of internal tourism potentials in Aqaba for the year (2016), and are as follows: hotels (2753), tourism agencies (156), tourism restaurants (1664), car rentals offices (38), tourism gift shops (82), diving centers (148), and water sports (255). All of those could benefit from the results of this research and imitate the other companies and centers that hosted tourism activities in Aqaba, and therefore, promote the internal tourism to Aqaba and raise the national income level.

\section{Research Goals}

This research aims for the following: 
1. Identify the most important natural potentials of Aqaba economical zone regarding the tourism attractions.

2. Identify the roles of the commissariat region authority of Aqaba Special economic zone in the tourism development of Aqaba economical city.

3. Identify the most important obstacles that face the internal tourism development of Aqaba economical city.

\section{Research Hypotheses}

1. Aqaba economical zone differentiate with a number of natural potentials regarding the tourism at tractions.

2. The roles of commissariat region authority of Aqaba Special economic zone participate in the tourism development of Aqaba economical city.

3. There are a number of obstacles that faces the internal tourism development of Aqaba economical city.

\section{Theoretical Framework and Previous Studies}

\subsection{Theoretical Framework}

Tourism represents an important resource from the resources and economics of many world countries, and the goals of tourism tangle with other sectors goals. Therefore, most of the world countries are dedicated to focus on the development of tourism for their economical impact on the various fields. The concerns about tourism in the Hashemite kingdom of Jordan start early, as recognition of this sector significance in the economical development of the country. The recent development plans cared about tourism and gives it a large importance, therefore a tourism development board was created at the state level, and on the Aqaba level a special commission of tourism was allocated in recognition of this sector's impact on the gross domestic product (GDP), balance of payments, providing job opportunities, and local community development. Figure 1 demonstrate the expected economic effects from the Jordanian tourism development, particularly the Aqaba region as a tourism attraction that leads to a tourism spending which require providing multiple economic fields, most importantly the investment in the tourism sector which serves the national economy.

Figure 1. The expected economic effects from Aqaba tourism development

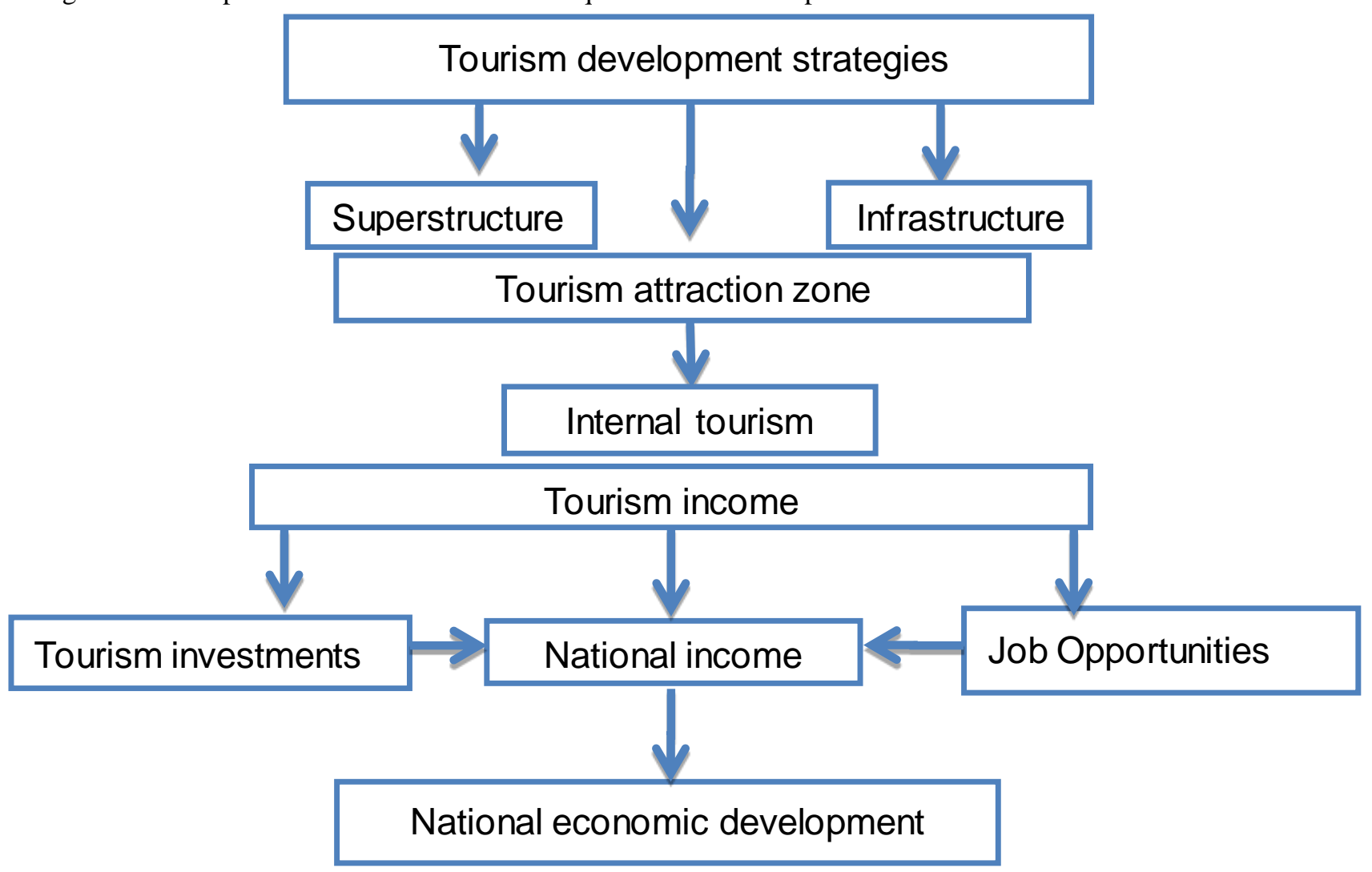

Source: researcher design

It shows from the previous figure that tourism development require the utilization of tourism potentials, and perhaps the most important of those are economic, environmental and cultural aspects and historical legacy 
which result from it an effective tourism projects, a matter that leads to tourism attractions, (GDP) increase, and jobs opportunities availability which helps in making a comprehensive development.

\subsubsection{Domestic Tourism in Jordan}

The specialized Jordanian studies in the tourism field indicate that the domestic tourism in the developed countries forms about $(90 \%)$ of the total tourism activity in these countries, meaning that foreign tourism pose only $(10 \%)$ from the overall tourism activity. While, the domestic tourism in Jordan contributed to only (7\%) from the overall tourism activity over the past decade (Bathatho, 2012, p. 21), and it's an indication that the domestic tourism in Jordan at its lowest, which requires redoubled efforts to increase the percentage of internal tourism contribution in support of tourism activity inside of Jordan. Revitalizing domestic tourism needs to combine all efforts, and attract the large numbers of citizens who are waiting from the operators of tourism promotion an offers and privileges to reduce the choice of turning to foreign tourism.

In this perspective, the ministry of tourism in the past few years headed to focus on the direction of internal tourism development through spreading the tourism awareness among the citizens about the tourism attractions of the Kingdom. The ministry launched in early October, 2012, a promotional and advertising campaign in cooperation with the tourism sector seeking to endorse and encourage domestic tourism, besides bringing the necessary investments by providing the tourism products and programs that meet the desire of citizens and local tourist who prefers the same day tourism on the overnight, and also the prices included in the campaign will be affordable by the citizens and will include all the tourism spots and locations in the Kingdom.(Ministry of tourism, 2012).

In this direction, Aqaba can be considers a rich and an attractive area for local, regional, and international investments. Aqaba is a first class tourism area, where travelers and tourists comes to it from all over the world, and internal tourism plays an important role in motivating the economical movement to Aqaba. In terms of importance, the golden triangle provinces in the South (Aqaba, Rum, and Petra) consider the second most important tourism region after Amman. Aqaba consider a major tourism center for leisure tourism, trade, and recently for conferences, and it is one of the most prominent attractive locations for internal or domestic tourism. (Bathatho, 212, P. 7).

In recent years, the regiments of Jordanian visitors to Aqaba become increasing by the day, and particularly in the holiday seasons and school holidays, and due to the tourism being an important economic resource and financial source for the treasury, decision makers in Aqaba requires to work on creating an investment environment adequate with the Aqaba tourism and economic location, and the return of economical and social benefits on the homeland and the Jordanian citizens.

\subsubsection{The Importance of Internal Tourism}

Tourism from an economic perspective is a productive sector that plays an important role in increasing the national income, and a source for providing employment opportunities, human resources development, and local community service. In this topic, a survey at the department of statistics on local tourism in 2008, showed that the number of trips by families residing in Jordan reached (1209.231), which divided into two type of trips: the one-day trips amounted to (951) thousands at $(78.6 \%)$ from the total number of local tourism trips, and the overnight trips amounted to (259) thousands, which represented a (21.4\%) of the overall trips. The survey showed that (57\%) from the one-day trips were for relaxation and vacation spending purposes, about (32\%) to visit relatives and friends, about (8\%) for school and university trips, (2\%) for shopping, and less than (2\%) for the rest. The overall tourism expenditure on those trips amount to (61.4) million JDs, the spending on the overnight trips amount to (32.7) millions approximately, forming a (53.3\%) from the total tourism expenditure, but for the one-day trips, the overall expenditure amounted to (28.7) millions JDs, forming a (46.7\%) from the total tourism expenditure. The survey results shows that Aqaba governorate received and treated a percentage of (38\%) from the overnight trips, and Aqaba governorate also took the first rank in the expenditure volume at percentage of (38\%) from the tourism expenditure (Department of statistics, 2008).

In the same prospective, opinion polls indicates that local tourist prefer the one-day tourism (78\%) on the overnight (21\%) (Addustour newspaper, 2010). Aqaba is the destination of the one-day tourists for the Jordanian visitors, forming (53\%) of the total domestic tourism, especially on weekends and holidays, and also the visitors coming from Amman governorate forms (51\%) from the overall visitors to Aqaba (PKF Jordan-Iraq, 2015, p.9).

The importance of domestic tourism can be represented in several aspects, and the most important one are: increase citizens ' awareness of the tourism importance to their country, including stunning natural attraction locations, historical and ancient monuments, and heritage sites, in order to deepen the national identity be longing, 
expand and increase the local communities interaction with the tourism attraction constituents, potentials, and locations. It will follow that, directing the attention and caring about the tourism environment characteristics and maintaining the cleanliness and the maintenance of the tourism sites. (Bathatho, 2012, p. 21).

Regardless of what was referred to previously regarding the importance of domestic or internal tourism in supporting the tourism activity, but the studies and reports highlight the numerous obstacles and problems that still interrupting the purposeful efforts to develop the prospects of domestic tourism in Jordan, which concentrate in the following points:

A. Reduce the per capita income rates and the living standards of Jordanians, which limit their abilities to spend on tourist activities, the large size of the Jordanian families, which reaches an average of about six persons increases the difficulties for saving and spending on activities, facilities, and tourism services. Although, there are the cultural constraints and obstacles that represented in the poor desire of citizens to visit the archaeological and historical monuments and areas. These constraints are associated with the poor cultural and tourism awareness about the significance of these tourism sites, landmarks, and attractions, add to that the limited and poor diversity of targeted tourism and recreational programs and activities for the different categories of the Jordanian society, in addition to the weaknesses of necessary incentives and promotional benefits to motivate the domestic tourism movement (Bathatho, 2012, p. 21).

B. The absence of the internal tourism marketing strategy to Aqaba: despite having a written strategy for marketing Aqaba tourism, but what's written differ from the actual, there is no clear strategy for marketing tourism to Aqaba. In addition, there are no clear marketing objectives, and also there is no consistency between the tourism marketing strategy and the actual market of (ASEZA). The reality confirms the existence of a strategic gap between what is needed to be achieved and what is actually achieved (Al-Ayman, 2013, p.50).

C. Hotel room quantities shortness: there is an urgent need for additional hotel rooms at Aqaba to ensure attracting greater number of tourists to visit it, knowing that the number of hotel rooms in Aqaba amount approximately to (4200) guestrooms, distributed on the one-star, and five star hotels. This limited capacity of hotels stand as a challenge to the tourism sector in Aqaba, The availability of large number of hotel rooms will enhance the operations of tourism promotion and will activate the domestic tourism, especially within the tourism promotion programs of the golden triangle (Alghad daily newspaper, 2015).

D. Shortness in the tourism services and weakness in the infrastructure and metadata (ultra-structure): Aqaba city visitors find almost no parking for their vehicles during the holidays, and vacations. Aqaba becomes very crowded in these periods which create obstacles in front of the Aqaba internal movement, and also the increasing number of visitors who sleep on pavements or sidewalks due to the lack of hotel rooms, particularly the classified three stars gives a negative appearance and indications on the movement of domestic or internal tourism. In addition, the limited parks and the crowded beaches of visitors along the city, as well as the traffic jamming are all considers an obstacles and constraints which officials must find appropriate solutions to them, in order to make Aqaba attractive and comfortable city for visitors.

\subsection{Previous Studies}

The Internal tourism studies gained great importance by researchers, stakeholders, and concerned parties due to their active role in increasing and improving the country's economic growth rates.

On the local level, the research of Bathatho (2012) aimed to illustrate the social and economic importance of Jordan's tourism sector, as well as displaying the central role of the tourism sector in directing and leading the Jordanian economy, and identifying the most important missed opportunities in the tourism sector, whether in the area of tourism development, investment, education, or other fields. The research also aimed to identify the required methods for restoring these lost opportunities through operational programs that will contribute to the advancement of Jordanian tourism industry.

The research arrived to several results, the most important are: the competitive capability of the Jordanian tourism sector suffered many obstacles, it is a necessity to lessen the applied regulations to allow the tourism transportation to work within and between the tourism sites, equipped it with the latest technological equipment in the sector, and also meets the tourists needs in the target markets. The research also found that tourism investment in Jordan is still at large part of it conventional, where it lacks the tourism therapeutic and educational investments, as well as the exhibitions, and conferences tourism, all kinds of different sports tourism, the desert, and the environment tourism.

In connection with the domestic tourism promotion in the developed countries, Maqableh research (2005) concluded that the most important factors contributed to the promotion of domestic tourism were site and place attractiveness, 
spending the holidays with families, friends, and relatives, and benefits from quotations or price discounts.

In a research conducted by the department of statistics (2008), which targeted the analytical report for the results of the local tourism survey in Jordan, the research concluded that the number of tourism trips for the one-day visitors were around (951) thousands at (78.6\%) from the overall number of local tourism trips, and the number of overnight trips amounted to (259) thousands at (21.4\%) of the overall number of tourism trips. In regard to the overall expenditure, it amounted to about (61.4) million JDs., the tourism expenditure on holidays and recreational trips was in first place, with about (40) million JDs from the overall tourism expenditure, spending for the purpose of relatives and friends visit came second with about (16) million JDs, while spending for shopping amount to about (3) million JDs only. The research also found that Aqaba governorate welcomes and treats (38\%) from the overnight trips, and the tourism expenditure in Aqaba came to (38\%) from the overall tourism expenditure.

In relation to the competitive indications in the tourism field, the research of Dupeyras \& MacCallum (2013) emphasized that understanding the country's competitiveness in tourism is one of the key considerations of policies and decision makers. The research seeks to divide the competitive indications in tourism into the following four indicators: indicators for measuring the tourism performance, indicators for monitoring the ability of the tourism area to provide quality and competitive tourism services, indicators for watching the attractiveness of the tourism area, and indicators for monitoring the responsiveness of policy makers to the available economic opportunities. The research found a number of major indicators to measure the competitive capability in the tourism field: consider the tourism GDP as a primary indicator for the tourism competitiveness, domestic tourism revenues per visitor, number of overnight stays in the various areas, and labor productivity in the field of tourism services.

Research performed by Al-Ayman (2013), the researcher aimed through it to evaluate the tourism marketing strategies at ASEZA, which was adopted by the authority in the period (2005-2010), and reached a number of results, the important one are: unclear tourism marketing strategy, unclear goals, as well as the lack of consistency between the tourism marketing strategy and the actual market for Aqaba Special economic zone. The research also found that tourism marketing strategy gap was largely caused by the inadequate budgets allocation to support tourism, in order to achieve the desired effect level, as well as lack of market researches and poor tourism promotion, therefore the decisions were based on personal assumptions rather than market researches.

\section{Research Methodology}

In order to achieve the previous research objectives, and arrive to the best methods and ways to highlight what Aqaba area possess of tourism potentials, as well as identify the most important obstacles that stand in the way of achieving an effective tourism development in Aqaba economic city, the researcher will rely on the following scientific methodologies:

Inductive method: for the purpose of examining and extrapolating some of the previous writings and studies related to the research topic, and how to benefit from them in solving the problem of the research.

The comparative method: for the purpose of comparing between the contributions of the other studies related to the research topic by standing at the findings and results, and how to benefit from them in overcoming the problem of the research.

Descriptive method: for the purpose of describing, explaining, interpreting, and analyzing the applied research results that the researcher will perform to test the research hypotheses and to verify the test results.

\section{Research Population and Sample}

The research population represented in all employers who work in tourism field, such as hotels, tourist agencies, restaurants, car rental offices, eastern artifacts shops, diving centers, and water sports for the year 2016, and table 2 represents the research society for the years (2011-2016):

Table 2. Number of Tourism Activities in Aqaba

\begin{tabular}{ccccccccc}
\hline Years & Hotels & $\begin{array}{c}\text { Tourism \& } \\
\text { agencies }\end{array}$ & $\begin{array}{c}\text { Tourism } \\
\text { restaurants }\end{array}$ & $\begin{array}{c}\text { Car rental } \\
\text { offices }\end{array}$ & $\begin{array}{c}\text { Tourism } \\
\text { shops }\end{array}$ & $\begin{array}{c}\text { Diving } \\
\text { centers }\end{array}$ & $\begin{array}{c}\text { Water } \\
\text { sports }\end{array}$ & $\begin{array}{c}\text { Overall } \\
\text { events } \\
\text { activities) }\end{array}$ \\
\hline 2011 & 55 & 40 & 124 & 12 & 41 & 9 & 3 & 284 \\
2012 & 55 & 35 & 124 & 12 & 41 & 9 & 3 & 279 \\
2013 & 59 & 30 & 124 & 12 & 41 & 9 & 3 & 278 \\
2014 & 63 & 34 & 124 & 12 & 41 & 9 & 3 & 287 \\
2015 & 64 & 34 & 124 & 12 & 41 & 9 & 3 & 307 \\
2016 & 64 & 34 & 124 & 12 & 41 & 26 & 6 & \\
\hline
\end{tabular}

Source: Ministry of tourism and antiquities (2016).

It perceives through table 2, that number of hotels (64), tourism agencies (34), restaurants (124), car rentals 
offices (12), Tourism shops (41), diving centers (26), and water sports (6), totaling (307) firms. A stratified random sample of them at $(10 \%)$ had been classified in the order of $(6,3,12,1,4,3,1)$, where the research tool was distributed on (34) of them, (32) were returned, and (2) were excluded after establishing that the respondents answered it without reading or interest.

\subsection{Data Collection Methods}

To complete the theoretical framework of the research, the researcher depended in the data collection process on several sources, such as books, literatures, Arabic and foreign periodicals, and the special publications of the Jordanian ministry of tourism and archaeology, as well as the researches of Arabic and foreign conferences, uni versity letters, theses, and dissertations, and the international information network (Internet). In regard to the field research, the researcher also depended on the questionnaire as a tool to identify the availability of natural potentials for the economic Aqaba area as a tourism attractions, as well as the role of (ASEZA) commissariat in the development of tourism at Aqaba economic city, and finally level of obstacles that faces internal tourism development in Aqaba economic City.

\subsection{Research Tool}

Researcher relied for data collection on the use of the questionnaire list method, where researcher has developed a questionnaire for this research and distributed it on the individuals concern with response to them totaling (34), and was received by hand-see supplement number (1). The questionnaire contains three main parts, the first part includes (14) articles covered the natural potentials of Aqaba economic area with relation to the tourism attractions, the second part contained (9) articles that addressed the role of (ASEZA) commissariat in the development of tourism at Aqaba economic city, and the third part contained (7) articles included the constraints and obstacles that faces the internal tourism development at Aqaba economic city, as shown in table 3:

Table 3. The three parts of questionnaire related to research sample

\begin{tabular}{llcc}
\hline \multicolumn{1}{c}{ Part } & \multicolumn{1}{c}{ Field } & $\begin{array}{l}\text { Articles } \\
\text { variables }\end{array}$ & for \\
\hline First part & Natural potentials of Aqaba economic area related to tourism attractions. & $1-14$ \\
\hline $\begin{array}{l}\text { Second } \\
\text { part }\end{array}$ & $\begin{array}{l}\text { Role of (ASEZA) commissariat in the development of tourism at Aqaba } \\
\text { economic city. }\end{array}$ & $15-22$ \\
\hline Third part & $\begin{array}{l}\text { Constraints and Obstacles facing the internal tourism development at Aqaba } \\
\text { economic city. }\end{array}$ & $23-30$ \\
\hline
\end{tabular}

In regard to the drafting of the research questionnaire, the researcher relied on the fourth Likert scale (strongly agree, agree, disagree, strongly disagree), and these answers were given the grades $(4,3,2,1)$ respectively, as shown in the table 4, where the arithmetic mean of (2) had been adopted to analyze the results.

\subsection{Statistical Operational Methods}

Researcher unloaded and analyzed questionnaire through the statistical package for social sciences (SPSS) software, and relied also on a number of statistical methods to analyze data, such as percentages and frequencies, Pearson correlation coefficient for measuring articles truthfulness, Cronbach alpha test to see the consistency of the articles on the questionnaire, Spearman-Brown formula for consistency, and the one sample average T-test.

\subsection{Research Limitations}

Spatial boundaries: the research was limited to Aqaba city and the tourism business and commercial firms available in it, such as hotels, restaurants, and various shops.

Temporal boundaries: the research limited to the time period of the tool distribution on the month of May, where a lot of tourists will come to the city, due to the mild weather at this time of the year.

Human limits: the research was identified by one social type represented in the employers.

Objective limits: subject of the research specified by the economic impact of domestic tourism only, and didn't cover the other effects which might result from the domestic tourism, such as social, political, or any other effects that may result from it.

\section{Result Anal ysis and Discussion}

In this part of the research, the researcher will display the results of the research, according to the following:

\section{First: the internal consistency of the research fields:}

To research the interaction between the three areas or fields, the correlation coefficients were calculated between these areas to show the impact of each one on the other, and the results according to table 4 were as follows: 
Table 4. Pearson correlation coefficients between the averages of the three areas (and the level of statistical significance for each)

\begin{tabular}{clccc}
\hline & & First field & Second field & Third field \\
\hline First field & Pearson coefficient & 1 & $0.46^{*}$ & 0.18 \\
(National income & Significant level & & 0.01 & 0.35 \\
increase) & Number of samples & 30 & 30 & 30 \\
\hline Second field & Pearson coefficient & 0.46 & 1 & -0.34 \\
(ASEZA) role & Significant level & 0.01 & 0.07 \\
& Number of samples & 30 & 30 & 30 \\
\hline Third field & Pearson coefficient & 0.176 & -0.34 & 1 \\
(Constraints and & Significant level & 0.35 & 0.07 & 30 \\
obstacles) & Number of samples & 30 & 30 & 30 \\
\hline
\end{tabular}

* Means that the correlation coefficient between the two variables is statistically significant at a level less than $(0.05)$.

It noticeable from table 4 above that the correlation coefficient between the first and second field was positive with (0.46) at statistical significance level of (0.01), but the correlation between the first and the third field was also positive with (0.18) at statistical signific ance level of $(0.35)$, while the correlation coefficient between the second and third fields came negative with (-0.34) at significance level of (0.07).

Then the limitation coefficients were calculated between the first field on the one side and the second and third fields on the other side, and the results were $(0.21),(0.11)$ respectively.

\section{Second: the natural potentials of Aqaba economic area with relation to the tourism attractions:}

Table 5 refers to the descriptive statistical results of the research sample opinions about the natural potentials of Aqaba economic area related to tourism attractions, thereon it is noticeable that the first article "the commercial traffic or movement increases on the weekend and on the tourism seasons." got the highest arithmetic mean at (3.13) out of (4), or (78\%) from the commercial employers believe that Aqaba owns a large potentials for the internal tourism which usually concentrate on the weekend and tourist seasons. Researcher believes that taking this article the lead in this area is an evidence on the truthfulness and practicality of the research, and this indicates that Aqaba possess the factors needed for the internal tourism attractions which would enrich the national economy and raise the Jordanian national income level. But the reason for obtaining article (12): "commercial slogans launch by (ASEZA) leads to an increase in the internal tourism (scatter the sand with gold.......)" the lowest arithmetic mean at (1.87) out of (4), or only (46\%), may be the non-arrival of sufficient publicity or advertisement of such slogans to the recipients in other provinces, the lack of continuity to launch such slogans by (ASEZA), or the emptiness of these slogans from the real and true substance that may achieve. The arithmetic mean for the whole domain or field reached (2.62) out of (4), or $(65 \%)$, it is acceptable percentage that indicate the existence of natural potentials of Aqaba economic area related to tourism attractions, and in turn proves the acceptance of the research first hypothesis.

Table 5. Descriptive statistics for the natural potentials of Aqaba economic area related to the tourism attractions

\begin{tabular}{|c|c|c|c|c|c|}
\hline $\begin{array}{l}\text { Article } \\
\text { number }\end{array}$ & Article & $\begin{array}{c}\text { Arithmetic } \\
\text { mean }\end{array}$ & STDEV & Seq. & T-value \\
\hline 1 & Commercial traffic increases on weekends and tourism seasons. & 3.13 & 0.78 & .000 & 22.114 \\
\hline 2 & There are special preparations on weekends to greet visitors. & 2.63 & 0.76 & .000 & 18.857 \\
\hline 3 & $\begin{array}{l}\text { Concentrate on one type of product on weekends and tourism } \\
\text { seasons. }\end{array}$ & 2.47 & 0.68 & .000 & 19.826 \\
\hline 4 & Jordanian tourists get treated better than the Arab tourist. & 2.47 & 0.94 & .000 & 14.417 \\
\hline 5 & Demand for labor increases on weekends and tourism seasons. & 2.37 & 0.76 & .000 & 16.947 \\
\hline 6 & Demand on goods led to an investment expansion. & 2.57 & 0.77 & .000 & 18.166 \\
\hline 7 & $\begin{array}{l}\text { Demand on hotel rooms increases over the weekends and tourist } \\
\text { seasons. }\end{array}$ & 3.10 & 0.66 & .000 & 25.658 \\
\hline 8 & Public traffic increases on weekends and tourist seasons. & 3.10 & 0.66 & .000 & 25.658 \\
\hline 9 & $\begin{array}{l}\text { Move ment of booking touris } m \text { buses increases on weekends and } \\
\text { tourist seasons. }\end{array}$ & 3.03 & 0.67 & .000 & 24.847 \\
\hline 10 & $\begin{array}{l}\text { Local populations are positively influenced by increasing the } \\
\text { tourism movement on weekends and tourist seasons. }\end{array}$ & 2.63 & 0.81 & .000 & 17.835 \\
\hline 11 & $\begin{array}{l}\text { The tourism movement increases in winter due to the mild } \\
\text { weather. }\end{array}$ & 1.97 & 0.81 & .000 & 13.320 \\
\hline 12 & $\begin{array}{l}\text { Commercial slogans launch by (ASEZA) leads to an increase in } \\
\text { the internal tourism (scatter the sand with gold.......). }\end{array}$ & 1.87 & 0.78 & .000 & 13.174 \\
\hline 13 & Jordanian tourists return to Aqaba more than once per year. & 2.83 & 0.87 & .000 & 17.750 \\
\hline 14 & $\begin{array}{l}\text { Most of the tourism groups makes Aqaba part of the ir journey, } \\
\text { for being one of the tourism golden triangle cornerstones (Petra, } \\
\text { Rum, Aqaba). }\end{array}$ & 2.47 & 0.97 & .000 & 13.882 \\
\hline & General level for the articles (1-14) & 2.62 & 0.87 & .000 & -5.347 \\
\hline
\end{tabular}


Third: roles of (ASEZA) commissariat in the development of tourism at Aqaba economic city.

Table 6 indicates the results of the research sample descriptive statistics related to the role of (ASEZA) commissariat in the development of tourism at Aqaba economic city. Therefore, article (15) "Tourism movement in Aqaba needs more organizations and arrangements" found to receive the highest arithmetic mean at (3.30) or (83\%). It is a very high percentage which decision makers in (ASEZA) must be aware of, due to the fact that organization process is the most important point in the success of any administrative action or work, therefore it must be reconsidered by directing and organizing the flow of internal tourism. Researcher sees that poor organization and arrangement may be due to the weakness of tourism awareness represented in delivering papers, publications, booklets, and brochures that identify and determine the locations and prices of tourist areas, apartments, hotels, or restaurants. All of this leads to lack of organization and the positioning of internal tourism only in the city center, for some reasons or another, and the poor organization also leads to traffic jams that limit the movement of people inside the city.

However, article (22) of this field: "ASEZA offer facilities in regard to the process of getting licenses and renewing them" got the lowest arithmetic mean at (1.60), or (40\%). Researcher sees two points of view for this issue, the first is against the procedures of (ASEZA) which employers sees as obstructive and disruptive to the tourism attractions, and as a result they hinder any increase in the national income, and the second view is about insuring the availability of the essential conditions in all tourism firms, in order to provide a superior services to the tourists. The arithmetic main for the domain or field as a whole came to (2.07) out of (4) or (51.7\%), which is a medium degree of support to the research sample, about the expected role of (ASEZA) commissariat contribution to the development of tourism at Aqaba economic city, which in turn proves the acceptance of second research hypothesis.

Table 6. Descriptive statistics for the role of (ASEZA) commissariat in the development of tourism at Aqaba economic city

\begin{tabular}{|c|c|c|c|c|c|}
\hline $\begin{array}{l}\text { Article } \\
\text { number }\end{array}$ & Article & $\begin{array}{c}\text { Arithmetic } \\
\text { mean }\end{array}$ & STDEV & Seq. & T-value \\
\hline 15 & $\begin{array}{l}\text { Tourism in Aqaba needs additional organization and } \\
\text { coordination. }\end{array}$ & 3.30 & 0.95 & .000 & 18.980 \\
\hline 16 & $\begin{array}{l}\text { (ASEZA) commissariat perform sufficient role to promote } \\
\text { internal tourism to Aqaba. }\end{array}$ & 1.73 & 0.83 & .000 & 11.470 \\
\hline 17 & $\begin{array}{l}\text { (ASEZA) commissariat performs the required procedures to } \\
\text { encourage the internal tourism to Aqaba. }\end{array}$ & 1.93 & 0.91 & .000 & 11.673 \\
\hline 18 & $\begin{array}{l}\text { (ASEZA) commissariat ensures that facilities are available to } \\
\text { the Jordanian tourists (baths, showers, and clubs). }\end{array}$ & 2.00 & 0.91 & .000 & 12.042 \\
\hline 19 & $\begin{array}{l}\text { (ASEZA) commissariat believes in conducting opinion polls } \\
\text { about the internal tourism to Agaba. }\end{array}$ & 1.73 & 0.91 & .000 & 10.465 \\
\hline 20 & $\begin{array}{l}\text { Tourists show some complaints about the exiting procedure } \\
\text { from the custom areas. }\end{array}$ & 2.83 & 0.99 & .000 & 15.747 \\
\hline 21 & $\begin{array}{l}\text { (ASEZA) commissariat provides facilities to dealers regarding } \\
\text { the entry and exit of goods from and to Aqaba. }\end{array}$ & 1.67 & 0.71 & .000 & 12.836 \\
\hline 22 & $\begin{array}{l}\text { (ASEZA) commissariat offer facilities in the licensing and } \\
\text { renewal processes. }\end{array}$ & 1.60 & 0.72 & .000 & 12.105 \\
\hline 23 & $\begin{array}{l}\text { (ASEZA) commissariat provides brochures, and guidebooks } \\
\text { with illustration about the commercial and tourism sites in } \\
\text { Aqaba. }\end{array}$ & 1.83 & 0.79 & .000 & 12.687 \\
\hline & General level for the articles (15-23) & 2.07 & 1.02 & .000 & -11.097 \\
\hline
\end{tabular}

\section{Fourth: obstacles that face the internal tourism development in Aqaba economic city.}

Table 7 indicates the results of the descriptive statistics for the research sample about "the obstacles that face the internal tourism development in Aqaba economic city", it is noticeable that article (27) "Aqaba needs an additional parking lots" received the highest arithmetic mean at (3.40) or (85\%) of employers believes, and this align with the researcher's point of view in the hypothesis number (3) emerging from this question, which supports that Aqaba needs immediate infrastructure and ultra-structure, where parking lots consider a real problem in Aqaba markets due to shortness in the specified parking or the absence of them in some of the important areas that have large shops and stores clustered together which are visited frequently by tourists and local populations, and draw the attention of (ASEZA) commissariat to develop the appropriate solutions to this problem.

While article (25) "Dealing with the Jordanian tourist better than dealing with the foreign tourists" got the lowest arithmetic mean at (2.20) or (55\%) of employer believes, where they see that dealing with the foreign tourists better than dealing with the Jordanian tourists. Researcher sees that the solution to this problem will be at 
distributing educational bulletin and brochures, and hire tourist guides in the crowded tourism areas to guide the tourists to their destinations.

Followed by the article (30) " The Jordanian tourists high cost limit their desires to come to Aqaba" which got an arithmetic mean of (3.20) or (80\%) from employers sees that the high cost of tourism to Aqaba limit the desires of Jordanian visitors to come to Aqaba. Researcher believes this to be an abuse and exploitation of the internal tourism, and to solve this problem, authorities must follow and control all the tourism facilities and firms, and make sure to display the price list of tourism services in a prominent place for everyone to see and follow. The arithmetic mean for the whole domain or field is (2.87) of (4) or (71.7\%), which is a high supporting percentage for the research sample about the existence of several constraints and obstacles that faces the internal tourism development at Aqaba economic city, which in turn proves the acceptance of the third research hypothesis.

Table 7. Descriptive statistics of obstacles that faces the internal tourism development at Aqaba economic city

\begin{tabular}{|c|c|c|c|c|c|}
\hline $\begin{array}{l}\text { Article } \\
\text { number }\end{array}$ & Article & $\begin{array}{c}\text { Arithmetic } \\
\text { mean }\end{array}$ & STDEV & Seq. & T-value \\
\hline 24 & $\begin{array}{l}\text { The prices of products increase on weekends and tourism } \\
\text { seasons. }\end{array}$ & 2.23 & 0.77 & .000 & 15.807 \\
\hline 25 & $\begin{array}{l}\text { Dealing with Jordanian tourists better than dealing with } \\
\text { foreign tourists. }\end{array}$ & 2.20 & 0.89 & .000 & 13.590 \\
\hline 26 & Aqaba needs an additional hotel rooms. & 2.90 & 0.88 & .000 & 17.953 \\
\hline 27 & Aqaba needs additional parking lots. & 3.40 & 0.67 & .000 & 27.603 \\
\hline 28 & Aqaba needs an additional promotions and advertisements. & 3.23 & 0.73 & .000 & 24.329 \\
\hline 29 & $\begin{array}{l}\text { Local population act negatively to the increase in touris } m \\
\text { movement in weekends and tourism seasons. }\end{array}$ & 2.90 & 0.88 & .000 & 17.953 \\
\hline \multirow[t]{2}{*}{30} & $\begin{array}{l}\text { High costs of Jordanian tourists limit the ir desires to come to } \\
\text { Aqaba. }\end{array}$ & 3.20 & 0.76 & .000 & 23.028 \\
\hline & General level for the articles (24-30) & 2.87 & 0.92 & .000 & -11.097 \\
\hline
\end{tabular}

\section{Research Results}

The research arrived to several results, the most important are as follow:

1. Research results showed that Aqaba economic zone differentiate with many natural potentials related to the tourism attractions, which was approved by the results of the research concerning the motivation of business and commercial movement on weekends and tourism seasons, which would enrich the national economy and raise the level of Jordanian national income, and this calls for to proofing the research first hypothesis.

2. Research results showed that the expected role of (ASEZA) commissariat in tourism development at Aqaba economic city needs additional enhancements and strengthening, especially in regard to the organization of the tourism movement in the region. Researcher believes that poor organization may be due to weak tourism awareness represented in the distribution of newspapers, brochures, and guidebooks which shows and specifies the locations and prices of the tourism areas, apartments, or restaurants, all of this leads to a lack of organization and the positioning of internal tourism only in the city center, and this calls for accepting the research second hypothesis.

3. Research results showed several obstacles that face the internal tourism development in Aqaba economic city, perhaps the most important are: lack of parking spaces to serve tourists inside Aqaba city, limited hotel rooms in Aqaba city, and the high cost of internal tourism to Aqaba city, and this calls for accepting the research third hypothesis.

\section{Recommendations}

Through the research results, researcher can recommends the following:

1. Increase the level of tourism awareness by (ASEZA) brochures, and guidebooks that will be distributed on tourists, and through supported tourism programs.

2. The continuous work on introducing the promotional presentations for tourists at the local, Arab and world levels in order to develop the internal tourism in Aqaba zone.

3. Work on providing, preparing, and creating the infrastructure and the superstructure at the Aqaba region to greet and entertain the tourists, especially in the formal holidays, tourism seasons, and weekends, such as increasing hotel suite, apartments, number of car parking, restaurants, etc).

4. Follow-up on all of the tourist facilities and firms, and check the price list regularly to work on promoting tourism, and so not exploiting tourists. 


\section{References}

Addustour newspaper. (2010). Great activity of domestic tourism and vogue for external. report of Jamal Khalifa, $15 / 11 / 2010$.

Al-Ayman, M. (2013). Tourism Marketing Strategy Case Study: Aqaba Special Economic Zone (ASEZA). International Business and Management, 6(1), 47-50. Available online at www.cscanada.net.

Alghad daily newspaper. (2015). website, report of Ahmed Al-Rawashdeh, date of publication, 15/5/2015.

Bathatho, I. (2012). Regain lost opportunities in the Jordanian tourism sector. economic and social report, research submitted to the Jordanian economic and social council, social and economic report, 2012, under the Jordanian strategic plan for the advancement of the national economy - tourism sector - During the period (2013-2018), page 7.

Department of statistics, reports. (2008). http://web.dos.gov.jo. https://doi.org/10.1787/5k47t9q2t923-en

Dupeyras, A., \& MacCallum, N. (2013). Indicators for Measuring Competitiveness in Tourism. OECDOrganization for Economic Co-operation and Development papers, available online at www.oecd.org.

Maqableh, K. (2005). The promotion of domestic tourism in the de veloping countries, analytical research of Jordanian experience from the point of view of a group of Jordanian tourists to Petra. Dirasat magazine, $32(3)$.

PKF, International Limited Network. (2015). Market Overview Aqaba- Jordan September 2015, Accountant \& Business Advisors, Available online at http://www.pkf.com/pkf-offices/europe-middle-east-andIndia/Jordan/pkf-jordan-amman-amman

The Jordanian ministry of tourism site. 
Appendixes: Questionnaire appendix

Dr.

Major:
Mr. / Mrs.

Work Field:

Researcher performs a study entitled: "The Role of Domestic Tourism in Supporting the National Economy, from the Point of View of Employers"Field Study on Aqaba Economical City

Kindly please fill out the questionnaire, thank you for your corporation.

\begin{tabular}{|c|c|c|c|c|c|}
\hline & & $\begin{array}{l}\text { Strongly } \\
\text { agree }\end{array}$ & Agree & Disagree & $\begin{array}{l}\text { Strongly } \\
\text { disagree }\end{array}$ \\
\hline \multicolumn{6}{|c|}{ 1st field } \\
\hline 1 & Commercial traffic increases on weekends and tourism seasons. & & & & \\
\hline 2 & There are special preparations on weekends to greet visitors. & & & & \\
\hline 3 & Concentrate on one type of product on weekends and tourism seasons. & & & & \\
\hline 4 & Jordanian tourists get treated better than the Arab tourist. & & & & \\
\hline 5 & Demand for labor increases on weekends and tourism seasons. & & & & \\
\hline 6 & Demand on goods led to an investment expansion. & & & & \\
\hline 7 & $\begin{array}{l}\text { Demand on hotel rooms increases over the weekends and tourist } \\
\text { seasons. }\end{array}$ & & & & \\
\hline 8 & Public traffic increases on weekends and tourist seasons. & & & & \\
\hline 9 & $\begin{array}{l}\text { Movement of booking tourism buses increases on weekends and tourist } \\
\text { seasons. }\end{array}$ & & & & \\
\hline 10 & $\begin{array}{l}\text { Local populations are positively influenced by increasing the tourism } \\
\text { movement on weekends and tourist seasons. }\end{array}$ & & & & \\
\hline 11 & The tourism movement increases in winter due to the mild weather. & & & & \\
\hline 12 & $\begin{array}{l}\text { Commercial slogans launch by (ASEZA) leads to an increase in the } \\
\text { internal tourism (scatter the sand with gold.......). }\end{array}$ & & & & \\
\hline 13 & Jordanian tourists return to Aqaba more than once per year. & & & & \\
\hline 14 & $\begin{array}{l}\text { Most of the tourism groups makes Aqaba part of their journey, for being } \\
\text { one of the tourism golden triangle cornerstones (Petra, Rum, Aqaba). }\end{array}$ & & & & \\
\hline \multicolumn{6}{|c|}{ ( } \\
\hline 15 & Tourism in Aqaba needs additional organization and coordination. & & & & \\
\hline 16 & $\begin{array}{l}\text { (ASEZA) commissariat perform sufficient role to promote internal } \\
\text { tourism to Aqaba. }\end{array}$ & & & & \\
\hline 17 & $\begin{array}{l}\text { (ASEZA) commissariat performs the required procedures to encourage } \\
\text { the internal tourism to Aqaba. }\end{array}$ & & & & \\
\hline 18 & $\begin{array}{l}\text { (ASEZA) commissariat ensures that facilities are available to the } \\
\text { Jordanian tourists (baths, showers, and clubs). }\end{array}$ & & & & \\
\hline 19 & $\begin{array}{l}\text { (ASEZA) commissariat be lieves in conducting opinion polls about the } \\
\text { internal tourism to Aqaba. }\end{array}$ & & & & \\
\hline 20 & $\begin{array}{l}\text { Tourists show some complaints about the exiting procedure from the } \\
\text { custom areas. }\end{array}$ & & & & \\
\hline 21 & $\begin{array}{l}\text { (ASEZA) co mmissariat provides facilities to dealers regarding the entry } \\
\text { and exit of goods from and to Aqaba. }\end{array}$ & & & & \\
\hline 22 & $\begin{array}{l}\text { (ASEZA) commissariat offer facilities in the licensing and renewal } \\
\text { processes. }\end{array}$ & & & & \\
\hline 23 & $\begin{array}{l}\text { (ASEZA) commissariat provides brochures, and guidebooks with } \\
\text { illustration about the commercial and tourism sites in Aqaba. }\end{array}$ & & & & \\
\hline \multicolumn{6}{|c|}{ 3rd field } \\
\hline 24 & The prices of products increase on weekends and tourism seasons. & & & & \\
\hline 25 & Dealing with Jordanian tourists better than dealing with foreign tourists. & & & & \\
\hline 26 & Aqaba needs an additional hotel rooms. & & & & \\
\hline 27 & Aqaba needs additional parking lots. & & & & \\
\hline 28 & Aqaba needs an additional promotions and advertisements. & & & & \\
\hline 29 & $\begin{array}{l}\text { Local population act negatively to the increase in tourism movement in } \\
\text { weekends and tourism seasons. }\end{array}$ & & & & \\
\hline 30 & High costs of Jordanian tourists limit their desires to come to Aqaba. & & & & \\
\hline
\end{tabular}

\section{Copyrights}

Copyright for this article is retained by the author(s), with first publication rights granted to the journal.

This is an open-access article distributed under the terms and conditions of the Creative Commons Attribution license (http://creativecommons.org/licenses/by/4.0/). 